\title{
Effect of Luteinizing Hormone-Releasing Hormone on the Release of Acetylcholine from Motor Nerve Terminals
}

\author{
MIKIE KOJIMA*, TAKASHI AKASU AND KYOZO KOKETSU \\ Department of Chemistry, Faculty of Science, Kyushu University, Fukuoka, 812* \\ and Department of Physiology, Kurume University School of Medicine, \\ Kurume, 830 Japan
}

Received for publication December 17, 1982

\begin{abstract}
Key words: LHRH - ACh-release - skeletal muscle end-plate - EPP miniature EPP - ACh potential
\end{abstract}

Neurotransmitters change the resting membrane potential of the postsynaptic cell (postsynaptic potentials) and also appear to modulate the release of neurotransmitters (Eccles, 1964). For example, the amount of acetylcholine (ACh) released from the preganglionic nerve terminals is modulated by catecholamines (Christ and Nishi, 1971; Kuba et al. 1981), 5 -hydroxytryptamine (Hirai and Koketsu, 1980), $\gamma$-aminobutyric acid (Kato and Kuba, 1980), ACh (Koketsu and Yamada, 1982) and adenosine triphosphate (Akasu et al. 1982).

Luteinizing hormone-releasing hormone (LHRH) is a neurotransmitter candidate for the late slow excitatory postsynaptic potential in bullfrog sympathetic ganglia (late slow EPSP) (Jan et al. 1979; Jan and Jan, 1982). In the present study, the effect of $\mathrm{LHRH}$ on ACh-release from the presynaptic nerve terminals of the frog neuromuscular junction was examined electrophysiologically. The results obtained suggest that LHRH at a low concentration $(4.6 \mu \mathrm{M})$ increases the amount of $\mathrm{ACh}$ released from the motor nerve terminal of sciatic nervemuscle preparations.

Sartorius muscles with intact sciatic nerves were isolated from frogs (Rana nigromaculata). These preparations were continuously superfused with Ringer solution. Conventional microelectrode techniques were employed for recording end-plate potential (EPP) using microelectrodes filled with $3 \mathrm{M} \mathrm{KCl}$ and having a tip resistance of $20 \mathrm{M} \Omega$. The ionic composition of the Ringer solution was $(\mathrm{mM}): \mathrm{NaCl} 112, \mathrm{KCl}$ 2, $\mathrm{CaCl}_{2} 1.8$ and $\mathrm{NaHCO}_{3}$ 2. 4. EPPs were induced by stimulating the motor nerve at a rate of $0.2 \mathrm{~Hz}$ in low $\mathrm{Ca}^{2+}$-high $\mathrm{Mg}^{2+}$ Ringer solutions $\left(\mathrm{CaCl}_{2}\right.$ 0.6-1. $1 \mathrm{mM}, \mathrm{MgCl}_{2}$ 4. 3-7. $0 \mathrm{mM}$ ) and in Ringer solution containing $\mathrm{d}$-tubocurarine $(\mathrm{d}-\mathrm{TC})(2 \mu \mathrm{M})$.

Quantal content was calculated by the variance method (del Castillo and Katz, 1954) from the mean amplitude and its standard deviation of 60 EPPs ( $5 \mathrm{~min}$ ) induced before, during and after the application of LHRH. Changes in the quantal content during the application of LHRH were expressed as a percentage of the mean quantal content. To obtain the $\mathrm{ACh}$ potentials, ACh was directly applied to the end-plate by microiontophoretic methods from a microelectrode filled with $1 \mathrm{M} \mathrm{ACh}$ with a tip resistance of $70 \mathrm{M} \Omega$.

(Send proofs and correspondence to Miss M. Kojima)

Department of Physiology, Kurume University School of Medicine, Kurume, 830 Japan 
A

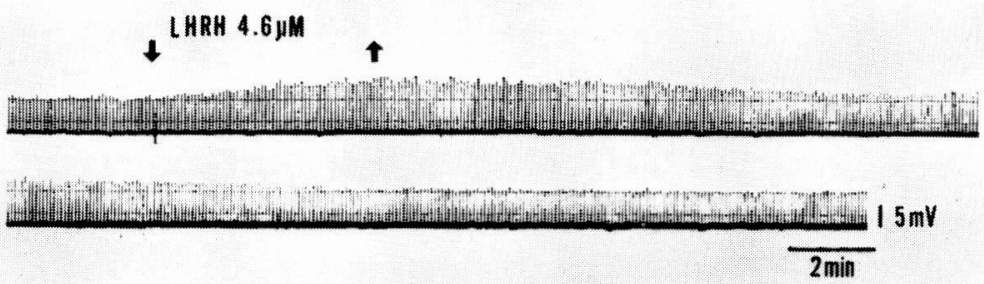

B

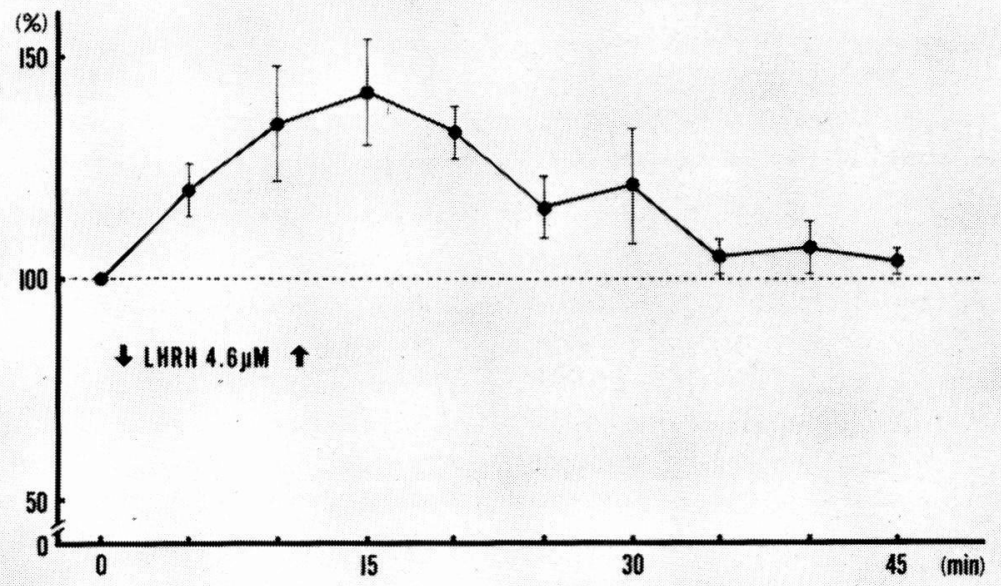

C
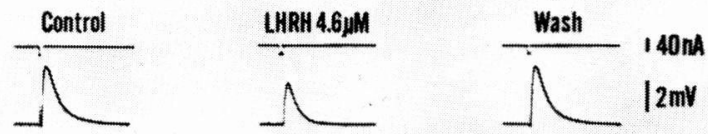

$5 \overline{\text { masec }}$

Fig. 1. Effects of LHRH $(4.6 \mu \mathrm{M})$ on the amplitude (A) and mean quantal content (B) of the EPP, and on ACh potentials (C) recorded from sartorius muscle end-plates. A: EPPs were recorded by stimulation of the sciatic nerve at a rate of $0.2 \mathrm{~Hz}$ in Ringer solution containing $2 \mu \mathrm{M} \mathrm{d}$-TC. LHRH $(4.6 \mu \mathrm{M})$ was applied between the downward and upward arrows. B: EPPs were recorded in a low $\mathrm{Ca}^{2+}$-high $\mathrm{Mg}^{2+}$ Ringer solution. The ordinate is the percent of the control quantal content of the EPP. The control mean quantal content (60 EPPs) is $100 \%$. Each vertical bar indicates the S.D. $(\mathbf{n}=7)$. Downward and upward arrows indicate the period of application of LHRH. C: The upper traces are the currents used for iontophoresis of $\mathrm{ACh}$. The lower traces are $\mathrm{ACh}$ potentials obtained by iontophoretic application of $\mathrm{ACh}$ to the end-plate region from a microelectrode filled with $1 \mathrm{M} \mathrm{ACh}$. 
All experiments were carried out at room temperature $\left(20-24{ }^{\circ} \mathrm{C}\right)$. The drugs used were acetylcholine chloride (Wako), d-TC (SIGMA) and LHRH (Protein research, Osaka).

Fig. 1-A shows the effect of LHRH (4.6 $\mu \mathrm{M})$ on the end-plate potential (EPP) elicited by motor nerve stimulation at a rate of $0.2 \mathrm{~Hz}$. The muscle was superfused with Ringer solution containing $2 \mu \mathrm{M} \mathrm{d}-\mathrm{TC}$ to suppress the generation of an action potential. When LHRH $(4.6 \mu \mathrm{M})$ was added to the superfusing solution, the resting membrane potential and resistance (input resistance) did not change, significantly. LHRH $(4.6 \mu \mathrm{M})$ increased the amplitude of the EPP to $149 \pm 8.8 \%$ (mean \pm S. D., $\mathrm{n}=4$ ) of the control value. The augmentation of the EPP was sustained throughout the application of LHRH. After removal of LHRH from the superfusing solution, the EPP did not change for $5 \mathrm{~min}$ and then gradually returned to the control amplitude. More than $25 \mathrm{~min}$ were necessary for complete recovery from the effects of LHRH. The facilitatory effect of LHRH on EPP amplitude was concentration-dependent. The minimum effective concentration of LHRH was $500 \mathrm{nM}$.

The quantal content of the EPP of skeletal muscle was determined in a low $\mathrm{Ca}^{2+}$ -high $\mathrm{Mg}^{2+}$ Ringer solution. Fig. 1-B shows the effect of LHRH $(4.6 \mu \mathrm{M})$ on the quantal content of the EPPs from 7 preparations. The quantal content slowly increased during the application of LHRH and reached a maximum value within $15 \mathrm{~min}$. When LHRH was removed from the superfusing solution, the augmentation of the quantal content was sustained for approximately $15 \mathrm{~min}$. The quantal content calculated by the variance method was increased by LHRH (4.6 $\mu \mathrm{M})$ to $142 \pm 11.7 \%$ of the control. Approximately $30 \mathrm{~min}$ after withdrawal of LHRH, the quantal content of the EPP returned to the control value. The facilitatory action of LHRH was dependent on the external $\mathrm{Ca}^{2+}$ concentration. In $\mathrm{Ca}^{2+}$ free Ringer solution, the EPP was completely eliminated and LHRH $(4.6 \mu \mathrm{M})$ could not restore the EPP. This indicates that LHRH does not act on the presynaptic nerve terminals as a substitute for $\mathrm{Ca}^{2+}$.

The possibility that the augmentation of the EPP by LHRH was due to an increase in the sensitivity of the nicotinic $\mathrm{ACh}$ receptor was examined. $\mathrm{ACh}$ potentials induced by microiontophoretic applications of $\mathrm{ACh}$ to the end-plate were reduced to approximately $73 \%(n=5)$ of the control amplitude by LHRH $(4.6 \mu \mathrm{M})$

(Fig. 1-C). The mean amplitude of miniature EPPs (MEPPs) was decreased to 82 $\%$ of the control amplitude by LHRH (4. 6 $\mu \mathrm{M})$. LHRH $(4.6 \mu \mathrm{M})$ did not alter the frequency of the MEPPs.

A presynaptic facilitatory action of LHRH was clearly demonstrated by these experiment. LHRH increased the amount of $\mathrm{ACh}$ released from motor nerve terminals of the frog sartorius muscle end-plate. These results also demonstrate that the sensitivity of the nicotinic $\mathrm{ACh}$ receptors at the skeletal muscle end-plates and bullfrog sympathetic ganglion cells are decreased by LHRH (cf. Akasu et al. 1983a).

LHRH at a low concentration depressed the after-hyperpolarization of action potentials and prolonged the duration of action potentials of bullfrog sympathetic ganglion cells (Akasu et al. 1983b). The duration of the $\mathrm{Ca}^{2+}$ spike (Minota and Koketsu, 1977) was also increased by LHRH (Akasu et al. 1983b). It was demonstrated with voltageclamp experiments (Akasu et al. 1983b) that LHRH markedly depressed the outward $\mathrm{K}^{+}$currents, $\mathrm{I}_{\mathrm{k}-1}$ (delayed rectifier $\mathrm{K}^{+}$ current) and $\mathrm{I}_{\mathrm{k}-2}$ (the $\mathrm{M}$ current, Brown and Adams, 1980). Furthermore, Akasu et al. (1983b) reported that LHRH at a low concentration $(5 \mu \mathrm{M})$ increased the amplitude of the slow inward current $\left(\mathrm{I}_{\mathrm{si}}\right)$ carried by $\mathrm{Ca}^{2+}$ (Akasu and Koketsu, 1981). It is tentatively concluded on the basis of these experimental results that LHRH increases the release of $\mathrm{ACh}$ from motor nerve termi- 
nals by increasing the $\mathrm{Ca}^{2+}$ current activated during the generation of action potentials in the presynaptic nerve terminals.

Acknowledgement: This study was supported in part by the Ministry of Education, Science and Culture of Japan.

\section{References}

Akasu, T., Hirai, K. and Koketsu, K. (1982). Modulatory effect of ATP on the release of acetylcholine from presynaptic nerve terminals in bullfrog sympathetic ganglia. Kurume Med. J. 29, 75-83.

Akasu, T., Kojima, M. and Koketsu, K. (1983a). Luteinizing hormone-releasing hormone suppresses the sensitivity of nicotinic ACh-receptor at amphibian sympathetic ganglion cell and end-plate. Neurosci. Lett. (in press).

Akasu, T. and Koketsu, K. (1981). Voltageclamp studies of a slow inward current in bullfrog sympathetic ganglion cells. Neurosci. Lett. 28, 259-262.

Akasu, T., Nishimura, T. and Koketsu, K. (1983b). Effect of luteinizing hormone-releasing hormone on the action potentials of bullfrog sympathetic ganglion cells. Neurosci. Lett. (in press).

Brown, D. A. and Adams, P.R. (1980). Muscarinic suppression of a novel voltage-sensitive $\mathrm{K}^{+}$current in a vertebrate neurone. Nature, 283, 673-676.

Christ, D. D. and Nishi, S. (1971). Site of adre- naline blockade in the superior cervical ganglion of the rabbit. J. Physiol. 213, 107117.

del Castillo, J. and Katz, B. (1954). Quantal components of the end-plate potential. J. Physiol. 124, 560-573.

Eccles, J.C. (1964). In The Physiology of Synapses. Berlin: Springer-Verlag. pp. 220-238.

Hirai, K. and Koketsu, K. (1980). Presynaptic regulation of the release of acetylcholine by 5-hydroxytryptamine. Br. J. Pharmac. 70, 499-500.

JAN, L. Y. and JAN, Y.N. (1982). Peptidergic transmission in sympathetic ganglia of the frog. J. Physiol. 327, 219-246.

Jan, Y. N., Jan, L. Y. and Kuffler, S. W. (1979). A peptide as a possible transmitter in sympathetic ganglia of the frog. Proc. Natl. Acad. Sci. U.S. A. 76, 1501-1505.

Kato, E. and KubA, K. (1980). Inhibition of transmitter release in bullfrog sympathetic ganglia induced by $\gamma$-aminobutyric acid. J. Physiol. 298, 271-283.

Koketsu, K. and Yamada, M. (1982) Presynaptic muscarinic receptors inhibiting active acetylcholine release in the bullfrog sympathetic ganglion. Br. J. Pharmac. 77, 75-82.

Kuba, K., Kato, E., Kumamoto, E., Koketsu, K. and HiraI, K. (1981). Sustained potentiation of transmitter release by adrenaline and $\mathrm{di}$ butyryl cyclic AMP in sympathetic ganglia. Nature, 291, 654-656.

Minota, S. and Koketsu, K. (1977). Effects of adrenaline on the action potential of sympathetic ganglion cells in bullfrogs. Jpn. J. Physiol. 27, 353-366. 